\title{
Determinants of turnover intentions among marketing and sales representatives in the UAE
}

\author{
Dr. Eappen Thiruvattal and Dr. Arun Prasad \\ Dubai Business School, University of Dubai \\ E-Mail : ethiruvattal@ud.ac.ae \\ E-Mail : arun@ud.ac.ae
}

\begin{abstract}
This article identifies four determinants of turnover intentions among the marketing executives and sales representatives (reps). Influence of these dimensions on such employees is investigated in an emerging market's Fast Moving Consumer Goods (FMCG) distribution environment.

Extensive review of the current literature on employee turnover intentions and specific review of turnover intentions among reps and marketing executives are conducted

This study identifies four dimensions of determinants of turnover intentions among marketing and sales representatives of FMCG in an emerging market. The results indicate that coordinated efforts by management to satisfy these dimensions lead to decreased turnover among marketing and sales reps of FMCG distributors.

This study offers understanding of the determinants of turnover intentions of turnover intentions among marketing and sales reps of FMCG distributors.

This article conceptualizes the influence of performance appraisal, developmental pay, talent acquisition and training, and learning and development on turnover intentions of Marketing and sales reps working in FMCG distribution industry. The article contributes to fill the knowledge gaps on the influence of these dimensions on turnover intentions.
\end{abstract}

Key words - Turnover intentions; Marketing and Sales representatives; Performance appraisal; HR strategies, Developmental pay, Talent acquisition.

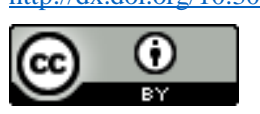

2523-6547 - Copyright: (C) 2017 The Authors. This is an open access article distributed under the terms of the Creative Commons Attribution License, which permits unrestricted use, distribution, and reproduction in any medium, provided the original author and source are credited. 


\section{INTRODUCTION}

Marketing and Sales reps are the front-line employees who link the organization with their buyers. Financial performance of B2B organizations are dependent on effective sales reps (Ahearne et al. 2010; Kumar et al. 2014). When a key rep leaves an organization, customers often tend to move to competitors, who provide better service. Such situation can be prevented temporarily by using contracts. However, customers may feel that they lost their important contact person, the replacement may not function as effectively, and they must build the relationship all over again. Organizations may develop broad and meaningful bonds, communicate the lofty standards of employees, and make the transition smooth to reduce such dissonance (Bendapudi and Leone, 2001). In the US market, approximately $7 \%$ of annual sales ( $\$ 500$ billion) are spent on salaries for the sales reps' annual sales decrease by $13.2 \%-17.6 \%$. Such loss can be mitigated to certain extent by existing sales representatives, while new recruits are not effective in reducing the losses (Shi et al., 2017). Even though such results recognized the importance of containing sales reps' turnover, studies to identify the determinants of their intentions in the GCC and Middle-East has been sparse. In this context, the current study will contribute to the existing literature on turnover intentions of sales and marketing employees in the region.

The next section of this article delineate a review of the current literature in turnover intentions in general and that related to sales reps in particular. Following that it provides a conceptual framework of the research topic.

\section{LITERATURE REVIEW}

Turnover intentions of employees have been studied about performance related pay (PRP) and profit sharing. A negative relationship is established between cumulative measure of PRP, profit sharing and turnover intentions (Halloran, 2012). With affective commitment employees desire to achieve goals of the organization by sharing their values, involving personally, and associating with the organization (Breitsohl and Ruhle, 2013). By engaging employees in the decision-making process, providing sufficient growth and development opportunities, maintaining work-life balance, providing adequate pay, and introducing various health and safety programs, organizations achieve reduced attrition rates. Such practices increase performance and commitment of employees (Grawitch et al., 2007). It is also indicated that employee development activities improved awareness of sacrifice. However, this often lead to greater turnover (Bambacasa, 2013).

To reduce turnover, job embeddedness through links, fit and sacrifice is found to be effective. Links are the employees' connection with other employees or the organization and fit is an employee's perceived compatibility with the organization (Ramesh and Gelfand 2010). The psychological or material cost an employee loses when he/she leaves the job is termed as sacrifices (Mitchell et al.2001, p. 1105). When the interactions between roles, responsibilities, relationships and experiences are improved, turnover intentions decrease (Holtom, Mitchell and Lee 2006). Job satisfaction increases when organizations provide PRP and profit share (Kruse et al., 2010). To increase organizational and employee performance, organizations use high performance work practices. These practices lead to ability, motivation and opportunity, hence enhancing employees' skills, motivating them, and providing opportunity to participate. Implementing the ability, motivation and opportunities (AMO) model results in sustainable employee performance leading to organizational citizen behavior (Organ, 1988) and reduced level of employee turnover intentions. Challenge in job, role of the given work, opportunities to develop, and supervisor's role are other reasons for citizen behavior (Sarikwal and Gupta, 2013). Providing employee tanning programs supported be performance appraisal and reward systems is an effective method of to reduce employee turnover (Paul and Ananntharaman 2004)

\subsection{Salesforce turnover intentions}

Major reason for sales force turnover is lack of job satisfaction. Antecedents of and results of job satisfaction are studied using meta-analysis. Work outcomes such as sales, organizational commitment are considerations for sales reps' turn over intentions. Other factors include individual differences in demography and job tenure, role perceptions in terms of ambiguity and clarity, and organizational factors such as behavior of supervisors, critical sales events, characteristics of the job, and task in hand. Organizational strategies that reduce job ambiguity reduces sales rep turn over intentions (Brown and Peterson, 1993; Chandrashekaran et al., 2000). Sales force embeddedness is recommended to reduce turnover intentions. As part of this, many organizations refer their sales reps as customer relationship managers (Bradford et al. 2010).

When retail industry organizations adopt non-conventional HR strategies to increase perceived external prestige, they experience low attrition rate and high organizational commitment. Commitment mediates partially between perceived external prestige and turnover intention. Particularly in countries with highly mobile workforce, increasing external prestige of the organization will lead to increased employee retention, organizational identification and commitment (Rathi and Lee, 2015, Ciftcioglu, 2011). Commitment is multi-dimensional in nature. It has a negative relationship with the intention to quit. Traditional belief prevails in the Middle-East that

2523-6547 - Copyright: (C) 2017 The Authors. This is an open access article distributed under the terms of the Creative Commons Attribution License, which permits unrestricted use, distribution, and reproduction in any medium, provided the original author and source are credited. 
committed employees provide a competitive advantage for the organization (Sulimana and Al-Junaibi, 2010). A committed employee will believe in the organization's goals and values, put considerable effort to achieve them, and will desire to continue working with the organization. Positive work experiences, personal and job characteristics play a key role in such committed employees. They exhibit effective performance, reduced absenteeism and turnover. While employee commitment acts as a deterrent to turn-over intention, satisfaction levels, perceived influence and perceived ease of gaining alternative employment play significant intervening effects on turnover intentions (Sager and Johnston, 1989). While continuance commitment lead in to employee commitment, intention uncertainty leads to turnover intentions (Chandrashekaran et al., 2000).

Impact of employee turnover in SMEs in the retail industry is such that losing a single talented employee can be detrimental to organizational objectives. Further, attracting and retaining talented employees are challenging tasks for them (Cardon and Stevens, 2004). Key HRM practices such as managing performance, administration of compensation policy, training, realistic job information, job analysis, work family balance, career development, and employee relations are useful tools to face such challenges (Jackson et al., 2012, Mathis and Jackson 2010; Longa et al., 2010, Abeysekera, R. 2007). Wrong perceptions about the job during the interview process leave employees with intention to leave. Close monitoring of workloads and relationship between supervisors and subordinates, flexible and shorter working hours, and benefits and recognition enhance employee retention among marketing executives. Other factors such as salary growth, meaningful work and opportunities, and job analysis are also important for retaining marketing executives (Abeysekera, R. 2007).

Research indicate that generation X employees (born 1960 and after) practice less organizational commitment than their older counterparts. They are better learners and tend to move more frequently from one organization to another. Experience generation X gained during their childhood and adolescence create the need for continuous learning and increasing capabilities and skills. Hence generation specific HR practices are more effective for employee retention (D'Amato and Herzfeldt, 2008; Kupperschmidt, 2000).

\section{CONCEPTUAL FRAMEWORK AND HYPOTHESES DEVELOPMENT}

According to social exchange theory, employees exchange communications with organizations as well as supervisors for their benefit (Masterson et al., 2000). Relationships originating through such communications are dependent on voluntary turnover. Shocking or jarring events in a work environment may lead to voluntary turnover intentions in sales reps (Mossholder et al., 2005). Better perceived quality in exchange relations create positive attitude among the employees. Higher level of interpersonal justice leads to employee commitment to their supervisors (Cropanzano et al., 2002). In a broader perspective, sales reps are influenced by sales managers, who are influenced by organization, which in turn is influenced by social, economic, political, and cultural status of the business environment (Boles et al., 2012). Performance appraisals conducted by management can have a positive or negative influence on turnover intentions of Marketing and sales executives. Hence the hypothesis:

H1. Performance appraisals by management has a direct influence on turnover intentions of Marketing and sales reps.

As per the classic agency model, organizations pay a sufficient compensation to their workers for the risk and effort due to PRP. Workers retain the same level of utility as the compensation they receive. Performance based pay and profit sharing increase job satisfaction, whereas, peace rate and commission based payment methods increase turnover rates (Geddes and Heywood, 2003). Performance based pay is hence an important factor that influence turnover intentions among marketing and sales reps. Hence the

H2. Developmental pay awarded to Marketing and Sales reps influence their intention to leave.

Talent acquisition and training is another factor that influence turnover intentions. Organizations adopt contentbased or process-based approach to implement their HR policies. The former strives to achieve an organization's goals by implementing a specific set of HR practices followed by the management, whereas the later give importance to psychological process by which employees perceive such practices. Employee perception can be positive or negative in nature (Chen and Wang 2014; Sanders and Yang 2015). Direct experience oriented sales training and higher goal oriented pre-call planning lead to better performance among sales reps (Leigh et al., 2014) H3. Talent acquisition has direct influence on turnover intentions of Marketing and sales reps.

Social exchange theory is also applied to predict turnover intentions due to procedural and interpersonal injustice in HR practices. Turnover intentions reduce when organizations have fair procedures and treat their employees with respect. Fair procedures lead to better perceived quality of exchange relationships (Flint et al., 2013).It is also noted that high performing sales reps have better procedural knowledge than their sales calls, leading to sales (Sharma et al., 2007). To improve the performance of sales reps, a long-term training program using discrimination tasks and explanations is often fruitful (Heit, 1994). Hence it is presumed that learning and development as a direct impact on turnover intentions of marketing and sales reps.

H4. Learning and development has direct influence on turnover intentions of Marketing and Sales reps.

2523-6547 - Copyright: (C) 2017 The Authors. This is an open access article distributed under the terms of the Creative Commons Attribution License, which permits unrestricted use, distribution, and reproduction in any medium, provided the original author and source are credited. 
Figure 1. Conceptual framework of determinants of turnover intentions of marketing and sales representatives

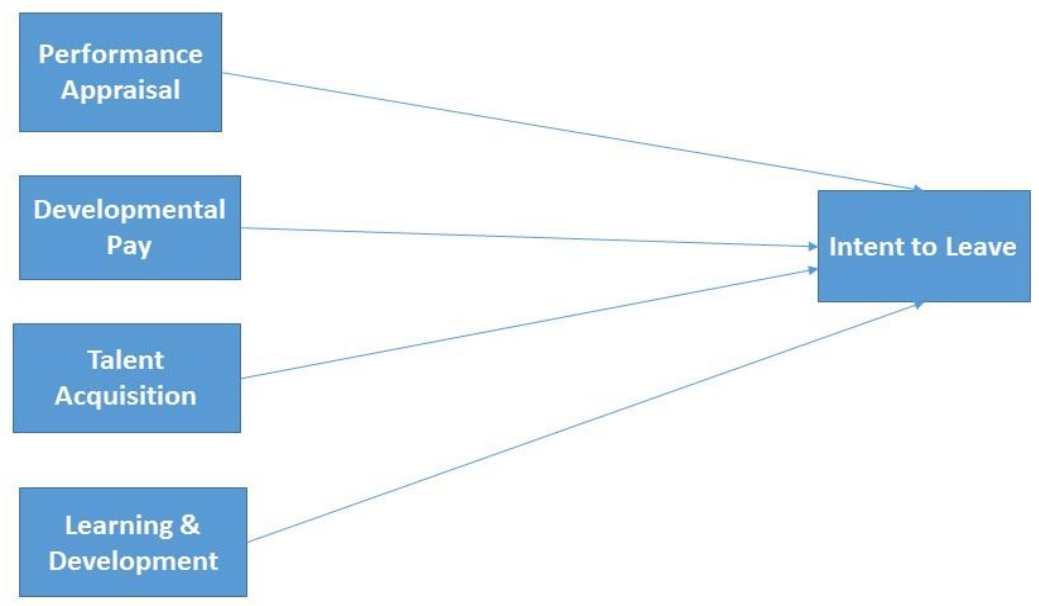

As depicted in figure 1, the conceptual framework has four dimensions and their variables have direct positive or negative influence on turnover intentions of Marketing and sales executives working in FMCG distribution. Primary data collection from marketing and sales reps of FMCG distributors from the UAE market representing different types of products, followed by confirmatory factor analysis using Smart PLS will be conducted to test these four hypotheses.

\section{CONCLUSION AND MANAGERIAL IMPLICATIONS}

Objective of this paper is to identify the determinants of turnover intentions among marketing executives and sales reps. Through extensive literature search four determinants namely performance appraisal, developmental pay, talent acquisition, and learning and development are identified. The results contribute to the existing knowledge on turnover intentions among marketing and sales reps. Managers may gain insight since no other published study has identified the determinants specifically to sales and marketing executives in the Middle East region. Due to the similarity in culture this study can be generalized to the Middle East region. 


\section{References}

Abeysekera, R. (2007), “The Impact of Human Resource Management Practices on Marketing Executive Turnover of Leasing Companies in Sri Lanka”, Contemporary Management Research Vol. 3 No. 3, pp. $233-252$.

Ahearne, M., and Lam, S. K. (2012), "Sales Force Performance: A Typology and Future Research Priorities," in Handbook on Business to Business Marketing, Gary L. Lilien and Rajdeep Grewal, eds. Cheltenham, UK: Edward Elgar Publishing, 496-520.

Bambacas, M., and Kulik, C.T. (2013), "Job embeddedness in China: how HR practices impact turnover intentions", The International Journal of Human Resource Management, Vol. 24 No. 10, pp. 1933-1952.

Bendapudi, N., and Leone, R.P. (2001), "How to Lose Our Star Performer Without Losing Customers, Too," Harvard Business Review, Vol. 79 No.10, pp. 104-15.

Boles, J.S., Dudley, G.W. Onyemah, V., Rouzies, D., and Weeks, W.A. (2012), "Sales Force Turnover and Retention: A Research Agenda," Journal of Personal Selling \& Sales Management, Vol. 32 No. 1, pp.131-40.

Bradford, K., Brown, S., Ganesan, S., Hunter, G., Onyemah, V., Palmatier, R., Rouziès, D., Spiro, R., Sujan, H. and Weitz B. (2010), "The Embedded Sales Force: Connecting Buying and Selling Organizations," Marketing Letters, Vol. 21 No. 3, pp. 239-253.

Breitsohl, H. and Ruhle, S. (2013), "Residual affective commitment to organizations: concept, causes and consequences", Human Resource Management Review, Vol. 23 No. 2, pp. 161-173.

Brown, S.P., and Peterson, R.A. (1993), “Antecedents and Consequences of Salesperson Job Satisfaction: MetaAnalysis and Assessment of Causal Effects," Journal of Marketing Research, Vol. 30 (February), pp. 63-77.

Cardon, M. S. \& Stevens, C. E. (2004), "Managing Human Resources in Small Organizations: What do We Know?" Human Resource Management Review, Vol. 14, pp. 295-323.

Chandrashekaran, M., McNeilly, K., Russ, F.A. and Marinova, D. (2000), "From Uncertain Intentions to Actual Behavior: A Threshold Model of Whether and When Salespeople Quit," Journal of Marketing Research, Vol.37 (November), pp. 463-79.

Chen, D., and Z. Wang. (2014), "The effects of human resource attributions on employee outcomes during organizational change", Social Behavior and Personality, Vol. 42 No.9, pp. 1431-1444.

Ciftcioglu, A. (2011), "The relationship between perceived external prestige and turnover intention: an empirical investigation", Corporate Reputation Review, Vol. 13 No. 4, pp. 248-263.

Cropanzano, R., Prehar, C.A. and Chen, P.Y. (2002), "Using social exchange theory to distinguish procedural from interactional justice", Group and Organizational Management, Vol. 27 No. 3, pp. 324-351.

D'Amato, A. and Herzfeldt, R. (2008) "Learning orientation, organizational commitment and talent retention across generations, A study of European managers”, Journal of Managerial Psychology, Vol. 23 No. 8, pp. 929953.

Flint,D., Haley, L.M., and McNally, J.J.(2013), Individual and organizational determinants of turnover intent, Personnel Review, Vol. 42 No. 5, pp.552-572.

Geddes, L.A. and Heywood, J.S. (2003), "Gender and piece rates, commissions, and bonuses", Industrial Relations, Vol. 42 No. 3, pp. 419-44.

Grawitch, M.J., Trares, S. and Kohler, J.M. (2007), "Healthy workplace practices and employee outcomes", International Journal of Stress Management, Vol. 14 No. 3, pp. 275-293.

O’Halloran, P. L. (2012) Performance pay and employee turnover., Journal of Economic Studies Vol. 39 No. 6 , pp. 653-674.

2523-6547 - Copyright: (C) 2017 The Authors. This is an open access article distributed under the terms of the Creative Commons Attribution License, which permits unrestricted use, distribution, and reproduction in any medium, provided the original author and source are credited. 
Heit, E. (1994). "Models of the Effect of Prior Knowledge on Category Learning." Journal of Experimental Psychology: Learning Memory and Cognition, Vol. 20 No. 6, pp. 1264-1282.

Holtom, B.C., Mitchell, T.R., and Lee, T.W. (2006), "Increasing Human and Social Capital by Applying Job Embeddedness Theory," Organizational Dynamics, Vol. 35, pp. 316-331.

Jackson, S.E., Schuler, R.S., and Werner, S. (2012), Managing Human Resources (11th ed.), Mason, OH: Cengage Learning.

Kruse, D.L., Freeman, R.B. and Blasi, J.R. (2010), “Do workers gain by sharing?”, in Kruse, D.L., Freeman, R.B. and Blasi, J.R. (Eds.), Shared Capitalism at Work: Employee Ownership, Profit and Gain Sharing, and Broad-based Stock Options, NBER, Chicago, IL, pp. 257-89.

Kumar, V., Sunder, S. and Leone, R. P. (2014), "Measuring and Managing a Salesperson's Future Value to the Firm," Journal of Marketing Research, Vol. 51 (October), pp. 591-608.

Leigh, T.W., DeCarlo, T.E., Allbright, D., and Lollar, J. (2014), "Salesperson Knowledge Distinctions and Sales Performance,” Journal of Personal Selling \& Sales Management, Vol. 34 No. 2, pp. 123-40.

Lin, Y. (2017), "Praise sales personnel for talent or effort? Person versus process-focused feedback, goal orientation and performance", Journal of Business \& Industrial Marketing, https://doi.org/10.1108/JBIM-102014-0208

Longa, C.S., Ajagbeb, M.A. and Kowangc, T. O. (2010), “Addressing the issues on employees' turnover intention in the perspective of HRM practices in SME", Procedia - Social and Behavioral Sciences, Vol.129, pp. 99 - 104

Masterson, S.S., Lewis, K., Goldman, B.M. and Taylor, M.S. (2000), "Integrating justice and social exchange. The differing effects of fair procedures and treatment on work relationships", Academy of Management Journal, Vol. 43 No. 4, pp. 738-748.

Mathis, R.L., and Jackson, J.H. (2010), Human Resource Management, Mason, OH: South-Western Cengage Learning.

Mitchell, T.R., and Lee, T.W. (2001), “The unfolding model of voluntary turnover and job embeddedness: Foundations for a comprehensive theory of attachment," Research in Organizational Behavior, 23, 189-246.

Mossholder, K.W., Settoon, R.P. and Henagan S.C. (2005), “A Relational Perspective on Turnover: Examining Structural, Attitudinal, and Behavioral Predictors," Academy of Management Journal, Vol. 48 No. 4, pp.607-618.

Organ, D. W. (1988). Organizational Citizenship Behavior - The Good Soldier Syndrome. (1st Ed.). Lexington, Massachusetts/Toronto: D.C. Heath and Company.

Paul, A.K., and Ananntharaman, R.N. (2004), 'Influence of HRM practices on organizational commitment: A study among software professionals in India,' Human Resource Development

Quarterly, Vol. 15, pp. 77-88.

Ramesh, A., and Gelfand, M.J. (2010), "Will they stay or will they go? The role of job embeddedness in predicting turnover in individualistic and collectivistic cultures," Journal of

Applied Psychology, Vol. 95, pp. 807-823.

Rathi, N., Lee, K. (2015) "Retaining talent by enhancing organizational prestige An HRM strategy for employees working in the retail sector," Personnel Review, Vol. 44 No. 4, pp. 454-469.

Sabnis, G., Chatterjee, S.C., Grewal, R., and Lilien, G.L. (2013), “The sales lead black hole: On sales reps' followup of marketing leads," Journal of Marketing, Vol.77 No.1, pp.52-67.

Sager, J.K., and Johnston, M.W. (1989), "Antecedents and outcomes of organizational commitment: A study of salespeople,” Journal of Personal Selling \& Sales Management, Vol. 9, pp. 3-41.

Sanders, K., and H. Yang. (2015), “The HRM process approach: The influence of employees' attribution to explain the HRM-performance relationship”, Wiley Periodicals, Inc. DOI: 10.1002/hrm.21661.

2523-6547 - Copyright: (C) 2017 The Authors. This is an open access article distributed under the terms of the Creative Commons Attribution License, which permits unrestricted use, distribution, and reproduction in any medium, provided the original author and source are credited. 
Sarikwal, L. and Gupta, J. (2013) "The impact of high performance work practices and organizational citizenship behavior on turnover intentions," Journal of Strategic Human Resource Management, Vol. 2 No.3, pp. 12-19. Sharma, A., Levy, M., and Kumar, A. (2000). "Knowledge Structures and Retail Sales Performance: An Empirical Examination”, Journal of Retailing, Vol. 76 No.1, pp. 52-69.

Shi, H., Sridhar, S., Grewal, R. and Lilien, G. (2017), "Sales Representative Departures and Customer Reassignment Strategies in Business-to-Business Markets", Journal of Marketing Vol. 81 No.3, pp. 25-44.

Suliman, A. A. and Al-Junaibi, Y. (2010), "Commitment and turnover intention in the UAE oil industry," The International Journal of Human Resource Management, Vol. 21 No. 9, (July), pp. 1472-1489.

Tandung,J. C. (2016), “The link between HR attributions and employees' turnover intentions", Gadjah Mada International Journal of Business, Vol. 18 No. 1, pp. 55-69.

Zoltners, Andris A., Prabhakant K. Sinha, and Sally E. Lorimer (2012), "Building a Winning Sales Management Team: A Managerial Perspective," in Handbook on Business to Business Marketing, Gary L. Lilien and Rajdeep Grewal, eds. Cheltenham, UK: Edward Elgar Publishing, 521-38. 
2523-6547 - Copyright: (C) 2017 The Authors. This is an open access article distributed under the terms of the Creative Commons Attribution License, which permits unrestricted use, distribution, and reproduction in any medium, provided the original author and source are credited. 